\title{
Use of artichoke (Cynara scolymus) flower extract as a substitute for bovine rennet in the manufacture of Gouda-type cheese: Characterization of aspartic proteases
}

\author{
Berta E. Llorente ${ }^{\mathrm{a}, *}$, Walter David Obregón ${ }^{\mathrm{b}}$, Francesc X. Avilés ${ }^{\mathrm{c}}$, Néstor O. Caffini ${ }^{\mathrm{b}}$, \\ Sandra Vairo-Cavalli ${ }^{\mathrm{b}, *}$ \\ a Plant Tissue Culture Laboratory (CULTEV), Department of Basic Sciences, National University of Luján, Buenos Aires, Argentina \\ ${ }^{\mathrm{b}}$ LIProVe, Departamento de Ciencias Biológicas, Facultad de Ciencias Exactas, UNLP, CC 711, 1900 La Plata, Argentina \\ ' Institut de Biotecnologia i de Biomedicina and Departament de Bioquímica i de Biologia Molecular, Universitat Autònoma de Barcelona, 08193 Bellaterra, Barcelona, Spain
}

\section{A R T I C L E I N F O}

Article history:

Received 28 November 2013

Received in revised form 26 February 2014

Accepted 2 March 2014

Available online 12 March 2014

\section{Keywords:}

Cardosin

Milk coagulation

Peptide-mass fingerprinting

Casein hydrolysis

\begin{abstract}
A B S T R A C T
Artichoke (Cynara scolymus L.) flower extract was assayed with the aim of replacing animal rennet in the manufacture of Gouda-type cheeses from bovine milk. Floral extract coagulated milk within a suitable time for use on an industrial scale, while the yield of cheese obtained was equal to that achieved with bovine abomasum. Five proteolytic fractions with milk-clotting activity were isolated in a two-step purification protocol, three belonging to the cardosin group. Cheeses made with $C$. scolymus proteases must be brined for a longer period $(40 \mathrm{~h})$ to prevent overproteolysis and avoid the development of a background flavor. The type of coagulant (bovine or vegetable) had no significant effect on the cheeses' chemical parameters analyzed throughout ripening, and no significant organoleptic differences were detected between those manufactured with $C$. scolymus or animal rennet. The results indicate that $C$. scolymus flower extract is suitable for replacing animal rennet in the production of Gouda-type cheeses.
\end{abstract}

(c) 2014 Elsevier Ltd. All rights reserved.

\section{Introduction}

Cheese is traditionally produced through the use of commercial calf rennet or rennet substitutes as enzymes of microbial origin, recombinant proteases metabolized by genetically modified microorganisms, and plant proteases (Jacob, Jaros, \& Rohm, 2011). Milk has a natural $\mathrm{pH}$ of 6.5 , while the $\mathrm{pH}$ optimum for the hydrolysis of $\kappa$-casein in the primary phase of rennet coagulation is 5.1-5.3 (Shalabi and Fox, 1982). The primary function of the enzymes in rennets is to destabilize the casein micelle and thus cause the gelation or coagulation of milk, but those hydrolases also play a major role in proteolysis during maturation of cheeses (Lane, Fox, Johnston, \& McSweeney, 1997). Substitutes with cheese-making potential should mimic calf rennet specific properties: a high ratio of clotting activity to proteolytic activity at $\mathrm{pH}$ and temperature of cheese-making as well as a sufficient thermolability to ensure whey products without remnants of active coagulant (Jacob et al., 2011). Many proteases that coagulate milk do not fulfil these

* Corresponding authors. Tel.: +54 2323 423979; fax: +54 2323425795 (B.E. Llorente). Tel.: +54 221 4230121x57; fax: +54 2214226947 (S. Vairo-Cavalli).

E-mail addresses: llorente@unlu.edu.ar (B.E. Llorente), svairo@biol.unlp.edu.ar (S. Vairo-Cavalli). requirements and are therefore unsuitable for cheese making. The generally used milk-clotting enzymes belong to the class of aspartic peptidases (APs), which are successful in bringing about the specific cleavage of the bovine- $\kappa$-casein Phe105-Met106 bond. The great majority of APs are optimally active at acidic $\mathrm{pH}$. During the processes of cheese manufacture and ripening, the limited action of the APs within the $\mathrm{pH}$ range of 4.5-6.5 is of particular interest. The primary function of the milk-clotting enzyme is to initiate the coagulation of the milk to which it has been added. This includes the rapid and highly specific cleavage of the hydrophilic caseinomacropeptide part from $\kappa$-casein molecules located at the periphery of the casein micelles (Dalgleish, 1987; Visser, 1993).

Vegetable enzymes from higher plant organs have been extensively investigated as potential coagulants in cheese making; nevertheless, some of them have been found to be unsuitable for cheese production owing to a characteristic excessive proteolytic activity that lowers cheese yield and produces bitter flavors in the final product. Among the vegetable enzymes that have been reported to produce satisfactory final products, cardosins and cyprosins (the proteases present in flowers of Cynara cardunculus L.) deserve special mention. Aqueous extracts of this thistle flower have been used for centuries in traditional artisanal farm production of ewe- and/or goat-milk cheeses such as Serra da Estrela, 
Manchego, La Serena, or Serpa in Portugal and Spain, some of them having Protected-Designation-of-Origin status (Jacob et al., 2011; Reis \& Malcata, 2011; Silva \& Malcata, 2005). Although artisancheese makers are small-scale producers, their production makes a substantial socioeconomical contribution to the dairy sector at regional areas of each country and thus makes a significant contribution to the local agricultural economy (Roseiro, Barbosa, Ames, \& Wilbey, 2003).

Cardosins A and B-the two APs mainly responsible for the clotting activity of such extracts-have been shown to act on $\kappa$-casein in a similar way to chymosin, cleaving the Phe105-Met106 peptide bond on bovine and ovine $\kappa$-casein, whereas caprine $\kappa$-casein is preferentially cleaved at Lys116-Thr117 (Silva \& Malcata, 2005). The two enzymes can also hydrolyze both $\alpha$ - and $\beta$-casein to produce cheeses characterized by a soft buttery texture, a typical aroma, and a slightly piquant and creamy flavor (Galán, Prados, Pino, Tejada, \& Fernández-Salguero, 2008). APs from C. cardunculus thistle are encoded by a multigene family (Pimentel, Van Der Straeten, Pires, Faro, \& Rodrigues-Pousada, 2007) and to date nine APs-the cyprosins A, B, and C and the cardosins A, B, E, F, G, and H-have been isolated, purified, and biochemically characterized from this plant (Sarmento et al., 2009). Cardosins and cyprosins-synthesized as single-chain zymogens with the subsequent conversion into the two-chain mature enzymes being a crucial step in the regulation of their activity-are dimeric, glycosylated, pepstatin-sensitive APs, active at acidic $\mathrm{pHs}$ (optimum at $\mathrm{pH} 4.5$ ), and with preferential specificity for peptide bonds between hydrophobic amino-acid residues (Sampaio, Fortes, Cabral, Pais, \& Fonseca, 2008; Sarmento et al., 2009). The cardosin C and D genes have also been described, although the predicted proteins have not yet been identified (Pimentel et al., 2007).

It is found in the literature that aqueous extracts from dried flowers of $C$. cardunculus-and such related species as $C$. scolymus and $C$. humilis, have been used for ages in the Iberian Peninsula, apparently ever since the Roman occupation in premedieval times (Lourenço, de Castro, Martins, Clemente, \& Domingos, 2002; Silva \& Malcata, 2000; Tejada, Vioque, Gómez, \& Fernández-Salguero, 2008). In addition to the species of the genus Cynara, Arctium minus, Centaurea calcitrapa, Cirsium vulgare, Onopordum acanthium, Onopordum turcicum, and Silybum marianum-all species included within the tribe: Cardueae Cass. = Cynareae Less, Asteraceae family-contain APs in their flowers with milk-clotting activity but without excessive proteolytic action (Brutti, Pardo, Caffini, \& Natalucci, 2012; Cimino, Liggieri, Priolo, Bruno, \& Vairo-Cavalli, 2010; Domingos et al., 2000; Lufrano et al., 2012; Silva \& Malcata, 2000; Tamer, 1993; Vairo Cavalli et al., 2008; Veríssimo, Esteves, Faro, \& Pires, 1995). In the case of $C$. scolymus, maximum proteolytic activity at pH 5.0 as well as easy enzyme inactivation by moderate heating, make this crude protease extract potentially useful for cheese production (Chazarra, Sidrach, López-Molina, \& Ródriguez-López, 2007; Llorente, Brutti, \& Caffini, 2004; Sidrach, García-Cánovas, Tudela, \& Rodríguez-López, 2005).

According to the United Nations Food and Agricultural Organization (FAO), in 2009 Argentina was the 9th cheese-producing country in the world. This industrial sector is by far the principal dairy product, accounting for approximately $45 \%$ of national milk production. The country has approximately 1000 cheese-manufacturing plants, and many plants of the leading companies along with several medium-sized enterprises operate according to the standards set by the International Organization for Standardization and observe the criteria for hazard analysis and critical control points (Cappellini, 2011). In 2010, Argentina's cheese exports amounted to about 52,000 metric tons, and in the first semester of 2013 its cheese exports had reached 24,189 metric tons, an output representing ca. 120 million dollars (free on board), according to the
Undersecretary of Dairy Products (Under Secretary of Dairy, Ministry of Agriculture, Livestock, Fisheries -SAGPAyA, 2010). Semi-hard cheeses (Gouda and Edam) represented $48 \%$ of the total volume, followed by soft (mainly Mozzarella) and hard (Goya and Reggianito) cheeses, with $33 \%$ and $18 \%$, respectively (Cappellini, 2011).

In this research we thus attempted to utilize aqueous extracts of the $C$. scolymus flower as a rennet substitute in the manufacture of Gouda-type cheese on a pilot scale and to characterize the APs present in those extracts. Even when the extracts of flowers of $C$. scolymus have been studied biochemically and its milk-clotting and proteolytic activities have been reported, to our knowledge, this is the first time that cheeses manufactured with this vegetable rennet are studied and characterized.

\section{Materials and methods}

\subsection{Plant material}

Mature flower heads of $C$. scolymus L. were obtained from farm plants grown in Nogoyá (Entre Ríos, Argentina) and La Plata (Buenos Aires, Argentina) collected in December and identified by Dr. Nancy Apóstolo, from the Plant Anatomy Laboratory, National University of Luján, Argentina.

\subsection{Reagents}

Bovine-serum albumin, cysteine, ethylenediaminetetraacetic acid (EDTA), glycine, pepstatin, and tris(hydroxymethyl)aminomethane were purchased from Sigma Chemical Co. (St. Louis, MO, USA), bicine and molecular-weight markers from GE Healthcare Biosciences (Uppsala, Sweden), casein (Hammarsten type) from Research Organics Inc. (Cleveland, OH, USA), bromophenolblue dye marker from Mallinckrodt Chemical Works (Paris, KY, USA), acrylamide, bisacrylamide, Coomassie brilliant blue G-250, and polyvinylidene-fluoride membrane from Bio-Rad (Hercules, CA, USA), Trypsin Gold from Promega Corporation (Madison, WI, USA), peptide calibrants and $\alpha$-cyano-4-hydroxycinnamic acid from Bruker Daltonics (Bremen, Germany), and San Regime ${ }^{\mathrm{TM}}$ powdered skim milk from SanCor (Sunchales, Argentina). All other chemicals were obtained from commercial sources and were of the highest purity available.

\subsection{Vegetable rennet}

Enzyme extracts were prepared following the method of Llorente et al. (2004). Artichoke flowers were ground under liquid nitrogen with a mortar and pestle and homogenized at a ratio of $1 \mathrm{~g}$ per $3 \mathrm{ml}$ of $0.1 \mathrm{M}$ potassium phosphate buffer ( $\mathrm{pH}$ 6.0) containing $1.0 \mathrm{mM}$ EDTA. The homogenized extracts were then filtered through two layers of gauze and finally centrifuged at $16,000 \times \mathrm{g}$ for $20 \mathrm{~min}$ at $4^{\circ} \mathrm{C}$.

\subsection{Milk-clotting activity}

Milk-clotting activity was measured following the procedure described by the International Dairy Federation Standard no. 157 (1992). A $100 \mu \mathrm{l}$-aliquot of sample was added to $1 \mathrm{ml}$ of skim milk reconstituted at $12 \%(\mathrm{w} / \mathrm{v})$ with $10 \mathrm{mM} \mathrm{CaCl}_{2}$ containing $0.02 \%(\mathrm{w} /$ v) sodium azide as a bactericide. The time elapsing at $37^{\circ} \mathrm{C}$ between the mixing of the reagents and the initial appearance of solid material was recorded. 


\subsection{Enzyme isolation}

Enzyme purification was carried out according to a modification of the procedure of Llorente et al. (2004) involving a two-step chromatography in an Äkta Purifier system (GE Healthcare Life Sciences Biosciences, Uppsala, Sweden). The extract was loaded onto a HiTrap Desalting column (Sephadex G25 Superfine, GE Healthcare Life Sciences) preequilibrated with $25 \mathrm{mM}$ Tris-Bicine buffer ( $\mathrm{pH}$ 6.0). The resulting depigmented-protein extract was recovered in the void volume and then loaded onto a HiTrap Q column (GE Healthcare Life Sciences), previously equilibrated with $25 \mathrm{mM}$ Tris-Bicine buffer ( $\mathrm{pH} \mathrm{6.0)}$ ). The bound material was eluted with two consecutive linear $\mathrm{NaCl}$ gradients $(0.10-0.35 \mathrm{M}, 0.35-0.50 \mathrm{M})$ followed by two steps of 0.5 and $1 \mathrm{M} \mathrm{NaCl}$ in the same buffer and the fractions containing milk-clotting activity pooled. Fractions from anion exchange chromatography were analyzed by SDS-PAGE according to the method described by Laemmli (1970); samples were separated on a $12.5 \%(w / v)$ gel using a Miniprotean III cell system (Bio-Rad). Gels were run at $60 \mathrm{~mA}$ for $45 \mathrm{~min}$ and then stained with Coomassie Blue G-250.

\subsection{Protein quantification}

The protein concentration was determined by the method of Bradford (1976) with bovine-serum albumin as reference standard for the calibration curve.

\subsection{Peptide-Mass Fingerprints (PMFs)}

Bands corresponding to the purified peptidases were cut out from the gel, washed first with Milli $\mathrm{Q}^{\mathrm{TM}}$ water and then with acetonitrile several times to remove the dye before drying under vacuum. For Cys-sulfhydryl alkylation, the gel fragments were treated with $0.1 \mathrm{M} \mathrm{NH}_{4} \mathrm{HCO}_{3}$ containing $10 \mathrm{mM}$ dithiothreitol for $30 \mathrm{~min}$ at $37^{\circ} \mathrm{C}$, centrifuged, washed with acetonitrile for $5 \mathrm{~min}$, and finally incubated in the dark in $0.1 \mathrm{M} \mathrm{NH}_{4} \mathrm{HCO}_{3}$ with $50 \mathrm{mM}$ iodoacetamide for $20 \mathrm{~min}$ at $25^{\circ} \mathrm{C}$. Digestions were carried out with $4 \mathrm{ng} / \mathrm{ml}$ trypsin for $12 \mathrm{~h}$ at $37^{\circ} \mathrm{C}$. The peptides obtained were recovered by extraction with a half volume of acetonitrile, dried in a SpeedVac vacuum centrifuge, and redissolved in $10 \mu \mathrm{l}$ of $1 \mathrm{ml} / 1$ trifluoroacetic acid. Each sample was spotted on a polished-steel plate and mixed with freshly prepared matrix solution $(10 \mathrm{mg} / \mathrm{ml}$ of $\alpha$-cyano-4-hydroxycinnamic acid in aqueous solution containing $30 \%$ acetonitrile and $0.1 \%$ trifluoroacetic acid by volume). PMFs were obtained by matrix-assisted-laser-desorption-and-ionizationtime-of-flight mass spectrometry (MALDI-TOF) in an UltraFlex MALDI-TOF mass spectrometer (BrukerDaltonics, Bremen, Germany). Spectra were obtained by means of Flex Control Software within a range of $c a .1000-3500 \mathrm{~m} / \mathrm{z}$. The external calibration was performed with peptide calibration standards.

MASCOT search tool (URL http://www.matrixscience.com) was used for identification of the related tryptic maps. The probability-based mowse (protein) score was calculated as $10 * \log (P)$, where $P$ is the probability that the observed match is a random event. Protein scores greater than 56 were considered significant $(p<0.05)$.

\subsection{Digestion of $\alpha-, \beta-$, and $\kappa$-casein by artichoke-flower APs}

The alpha, beta, and kappa caseins purified by the method of Rusconi, Priolo, López, and Vairo Cavalli (2011) were kindly provided by Elina Rusconi, MSc (LIProVe, Faculty of Exact Sciences, University of La Plata). Reactions were started by the addition of $300 \mu \mathrm{l}$ of $0.80 \mathrm{mg} / \mathrm{ml} \alpha$ - or $\beta$-casein or $0.65 \mathrm{mg} / \mathrm{ml}$ of $\kappa$-casein to $30 \mu \mathrm{l}$ of each purified enzyme (which volume corresponded to $60 \pm 4 \mu \mathrm{g}$ of peptidase $/ \mathrm{ml}$ ). At 30 and $60 \mathrm{~min}$ the reactions were quenched by the addition of $2 x$ sample buffer for sodiumdodecylsulfide-polyacrylamide-gel electrophoresis (SDS-PAGE); then samples were heated at $100^{\circ} \mathrm{C}$ for $5 \mathrm{~min}$. Controls containing each casein, at the same concentration but without addition of enzyme, were also included.

Hydrolysis was analyzed by SDS-PAGE according to Laemmli (1970); samples were separated on $12.5 \%$ acrylamide gels using a Mini Protean III cell system (Bio-Rad). Gels were run at $60 \mathrm{~mA}$ for $45 \mathrm{~min}$ and then stained with Coomassie Blue G-250. After separation, the bands were blotted onto a polyvinylidene-fluoruide membrane through the use of the Mini Trans-Blot system (BioRad) in $10 \mathrm{mM}$ CAPS buffer (N-cyclohexyl-3-aminopropanesulfonic acid) plus $10 \%(\mathrm{v} / \mathrm{v}$ ) methanol, $\mathrm{pH} 11.0$. N-terminal sequencing was performed by the Sequencing Services of LANAIS-PRO (CONICETUBA) via Edman degradation.

\subsection{Formulation of Gouda-type cheese from bovine milk}

The extracts obtained in Section 2.3 were used as plant coagulants to produce semihard cheeses. Standard manufacturing conditions for bovine-rennet-curdled cheeses-according to the FAO of the World Health Organization (1986)-were followed through the entire cheese-making process by a protocol optimized at the Pilot Plant of Research and Development Center of National University of Luján (CIDETA-UNLu). Milk produced from Holando Argentino dairy cows was obtained from National University of Luján dairy (Dairy Production Unit; Teaching, Research and Outreach Center for Farming Production) and pasteurized at $72{ }^{\circ} \mathrm{C}$ for $15 \mathrm{~s}$ before use. Two hundred $\mathrm{l}$ of pasteurized milk (fat and protein content 34.0 and $31.4 \mathrm{~g}$ per 1 , respectively) were transferred to a 500-l cheese vat (Bauducco, El Trébol, Santa Fe, Argentina) and the acidity adjusted to $16^{\circ}$ Dornic with food-grade acetic acid. The milk was then inoculated with a mesophilic starter culture CHN11 (CHR Hansen, Quilmes, Argentina) and incubated to $32{ }^{\circ} \mathrm{C}$ for $1 \mathrm{~h}$ before rennet addition. Bovine rennet $(0.6 \mathrm{ml}$ per $10 \mathrm{l}$ of milk) (Cortafor-T, Tuteur SACIFIA, Buenos Aires, Argentina) or artichoke-flower extract ( $30 \mathrm{ml}$ [54 $\mathrm{mg}$ of protein] per $10 \mathrm{l}$ of milk) was added to curdle the milk at $35^{\circ} \mathrm{C}$. The milk was kept undisturbed until coagulation was complete. The curd was cut with blades left to heal for $5 \mathrm{~min}$, and then gently stirred mechanically for $5 \mathrm{~min}$. The temperature was raised gradually to $40{ }^{\circ} \mathrm{C}$ over a period of $15 \mathrm{~min}$, and the curd was then washed with chlorine-free water before a second step of cutting and stirring was performed under the same conditions.

The curd was packed into cylindrical molds and pressed $(2.0 \mathrm{~kg} /$ $\mathrm{cm}^{2}$ ) at $20^{\circ} \mathrm{C}$ for $1 \mathrm{~h}$. Five cheeses were produced with animal rennet (AR) and 10 with vegetal rennet (VR). The curds were salted by brining in $\mathrm{NaCl}$ solution $\left(22^{\circ} \mathrm{B}\right)$. Vegetable-curd cheeses were separated into two groups; the first group was brined for $30 \mathrm{~h}$ (VR-30) and the second group for $40 \mathrm{~h}$ (VR-40). AR cheeses were salted for $30 \mathrm{~h}$. Finally cheeses were transferred to a ripening chamber for a 44-day storage at $14^{\circ} \mathrm{C}$.

After this treatment the cheeses were analyzed for total and water-soluble nitrogen content (TN and WSN, respectively) by the semimicro-Kjeldahl method (AOAC, 1984), moisture by oven drying (AOAC, 1984), and internal and external pH by direct contact of the cheese with an electrode having a protective plastic cover (Hanna Instruments, Buenos Aires, Argentina). A determination of the change in those parameters over time was performed on three samples chosen at random for each treatment, whereas the $\mathrm{pH}$ and humidity were measured at the end of ripening on two samples of every cheese. The casein-hydrolysis profile was analyzed by urea-PAGE according to the method of Shalabi and Fox (1987). The TN and soluble-casein content were determined in duplicate with three cheeses from each treatment. A quantification of the intact caseins was done by gel scanning followed by 
densitometry through the use of the software Scion Image Beta v. 4.02 for Windows (Scion Corporation, Frederick, MA, USA).

Triangular discriminative tests (Lawless \& Heymann, 1999) were performed in order to detect differences between the bovine-rennet cheeses and those made with artichoke-flower extract salted for either 30 or $40 \mathrm{~h}$. A sensory analysis was performed by a panel of 12 trained judges. Three samples of each product were presented to each panelist, who tested two equal samples and a different one. Both the external and the internal appearance, as well as the texture and flavor of the cheese at the end of the ripening process, were evaluated. Precautions were taken to randomize the samples, to mask the identity, and to minimize the effects of contrast and adaptation.

\subsection{Statistical analysis}

Statistical evaluation by the one-way analysis of variance (ANOVA) was performed by means of statistical software (IBM-SPSS v19). Tukey's comparison was used to determine the significance between groups. A $p$-value $\leqslant 0.01$ was considered significant. The results are reported as the mean \pm standard error of the mean, with the latter being used as an indication of the uncertainty in each measurement.

\section{Results and discussion}

\subsection{Purification}

Crude extract from fresh flowers of C. scolymus L. (artichoke), exhibited milk-clotting activity (time $<2 \mathrm{~min}$ ). Llorente, Brutti, Natalucci, and Caffini (1997) originally provided evidence that the curdling activity of extract from the inflorescence of $C$. scolymus at various stages of development is caused by APs. In subsequent studies, Llorente et al. (2004), using fresh or frozen artichoke flowers, obtained peptidase homogenates at $\mathrm{pH} 6.0$ with maximal proteolytic activity at $\mathrm{pH} 5.0$ and a pI of around 4.0. Employing adsorption with activated charcoal followed by anion-exchange and affinity chromatography, those authors isolated two main protein heterodimeric fractions consisting of a 30- plus a 15-kDa subunit, both with acid-proteolytic and milk-clotting activities. In contrast, three proteinases with milk-clotting activity were isolated from the stigmas of artichoke flowers by Sidrach et al. (2005); these proteases were later partially characterized by Chazarra et al. (2007), who named them cynarases A, B, and C. The two-step purification procedure used in the present work, based on that chromatographic procedure of Llorente et al. (2004), resulted in 5 fractions ( $a, b, c, d$, and e) with milk clotting activity (Fig. 1A). All the enzymes were heterodimeric proteins with two subunits of apparent molecular masses of 30 and $14.4 \mathrm{kDa}$ (Fig. 1B) as estimated by SDS-PAGE. The five isolated enzyme fractions, at concentrations of $50 \mu \mathrm{g} / \mu \mathrm{l}$, exhibited milk-clotting activity: fractions $b, c, d$, and $e$ did so at times of less than $30 \mathrm{~min}$, while Fraction $a$ coagulated milk only after $20 \mathrm{~h}$. We cannot conclude that the enzymes purified in the present work correspond to the cynarases cited in the literature, as even when the authors characterized those enzyme fractions, no DNA-sequential nor the $\mathrm{N}$ termini analyses were made. The increase in the number of purified fractions in this work is not unexpected, since, as demonstrated for cardoon APs, these enzymes apparently belong to a multigene family (Pimentel et al., 2007).

\subsection{Enzyme characterization}

\subsubsection{PMFs}

The Coomassie-blue-stained bands of the 30-kDa subunits from each fraction were excised from the polyacrylamide gels and digested with trypsin. The resulting peptides were then analyzed by mass spectrometry (Fig. 1 in Supplementary Data). The PMFs were compared to protein sequences present in the nonredundant database as summarized in Table 1 . Several peaks were found to be repeated in the different spectra analyzed. It is quite common to see several proteins getting the same high score. Even if the protein sequences in the database are nonidentical since the same group of matched-mass values may nevertheless occur in multiple proteins (http://www.matrixscience.com/help/pmf_summaries_help.html). Six experimental tryptic fragments of Fraction $a$ matched peptides of cardosin $\mathrm{H}$ (score, 90) with a sequence coverage of $57 \%$ and a satisfactory peptide distribution. A good correlation was also found between the number of matching peptides, the score and the percentage of coverage with cardosin $\mathrm{F}$ (score, 69; major subunit sequence coverage, $41 \%$ ), and procardosin $\mathrm{A}$ (score, 57 ; major subunit sequence coverage, 36\%). Eight digested peptides of Fraction $b$ matched cardosin $\mathrm{H}$ (score, 98.90; sequence coverage, 45\%) and procardosin A (score, 78\%; sequence coverage, 23\%). The Fraction-c PMFs were well correlated with cardosin $\mathrm{H}$ (score, 97; sequence coverage, 45.3\%), procardosin A (score, 87; sequence coverage, $23.8 \%$ ), and cardosin $\mathrm{E}$ (score, 58; sequence coverage, 39.7\%). The peptides with $m / z$ 1303.55; 1708.71, and 2,994.35 from the tryptic digest of Fraction $b$ and the peptides with the same $m / z$ of 1303.59, 1708.76, and 2994.39 from Fraction $c$ comprised the $\mathrm{N}$-terminal (residues 1-29) of mature cardosin A and cardosin $\mathrm{H}$, consistent with the first 20 residues (i. e., the $\mathrm{N}$-terminal sequence) obtained by Llorente et al. (2004) through Edman sequencing of the species in their peak IV. The sequence identity between the major subunits of procardosin A and cardosin $\mathrm{F}$ (C. cardunculus) is $86 \%$ (with $88 \%$ positives), while the correspondence between the heavy subunits of procardosin $\mathrm{A}$ and cardosin $\mathrm{H}$ is $82 \%$ (with $82 \%$ positives) and between the former and cardosin $\mathrm{E} 60 \%$ (with $61 \%$ positives). It is also noteworthy that the available sequences of cardosin $\mathrm{H}, \mathrm{F}$, and $\mathrm{E}$ are not complete, but rather contain several gaps. Mature flowers of $C$. cardunculus (cardoon) produce two identified groups of typical plant APs-cardosins and cyprosins (Sandra Vairo Cavalli, Lufrano, Colombo, \& Priolo, 2013). In view of the foregoing data, $C$. scolymus fractions $a, b$, and $c$ clearly belong to the cardosin group. Further investigation, however, is needed in order to elucidate the complete sequences of these enzymes.

The PMFs of fractions $d$ and $e$ were identical to each other but even with a high peptide-mass tolerance employed (1000 ppm), no matches were found, indicating the presence of significant differences in the primary sequences from those available in the database. Nevertheless, some of the spectral peaks of fractions $d$ and $e$ are coincident with the PMF peaks of the other fractions or even with the $\mathrm{m} / \mathrm{z}$ values corresponding to a theoretical digest of the cardosins available in the data base (e.g., peak $m / z 969.4$ is present in fractions $b, c, d$, and $e$; procardosin $\mathrm{A}$; and cardosins $\mathrm{H}$ and $\mathrm{E}$ ).

\subsubsection{Casein-hydrolytic profile}

The degradation pattern of $\alpha_{\mathrm{s}^{-}}, \beta-$, and $\kappa$-caseins hydrolyzed by fractions $b, c$, and $e$ was visualized by SDS-PAGE (Fig. 2). A breakdown of either $\beta$ - or $\kappa$-casein was observed after 30 min with each enzymatic fraction; but the hydrolytic profiles showed a specific activity for all the fractions without excessive proteolysis, and in all instances a principal degradation fragment was present. Conversely, the $\alpha$-caseins were less susceptible to proteolysis by the isolated enzyme fractions, and after 60 min the protein degradation was only partial under the assay conditions used.

Peptides produced by $\kappa$-casein digestion were analyzed by Edman sequencing. The isolated APs fractions from $C$. scolymus extract possessed a specificity such that, in addition to hydrolyzing the $\kappa$-casein Phe105-Met106 bond, fractions $b, c$, and $e$ cleaved the Tyr42-Tyr43 bond and Fraction $e$ also split the Leu50-Ile51 bond, both of the hydrophobic N-terminal peptide, para- $\kappa$-casein; as 
A

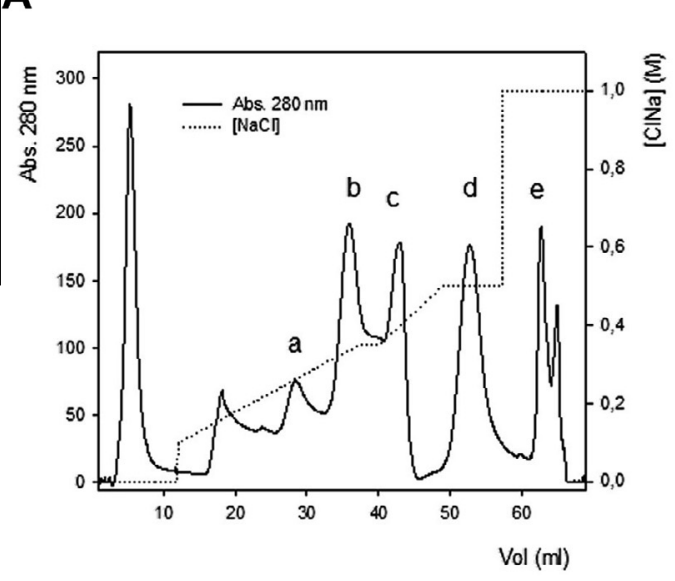

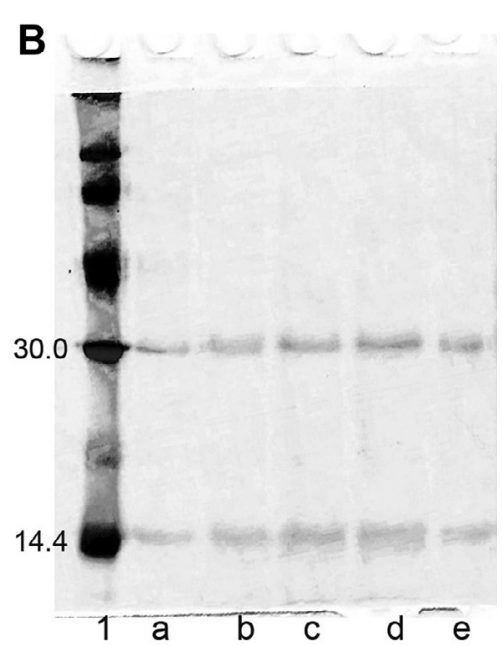

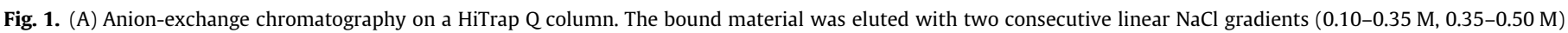

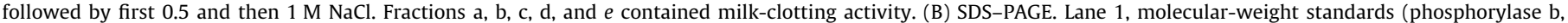

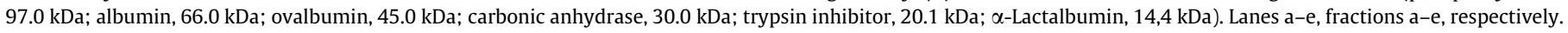

Table 1

Identification of trysin-digested peptides from fractions $a-c$.

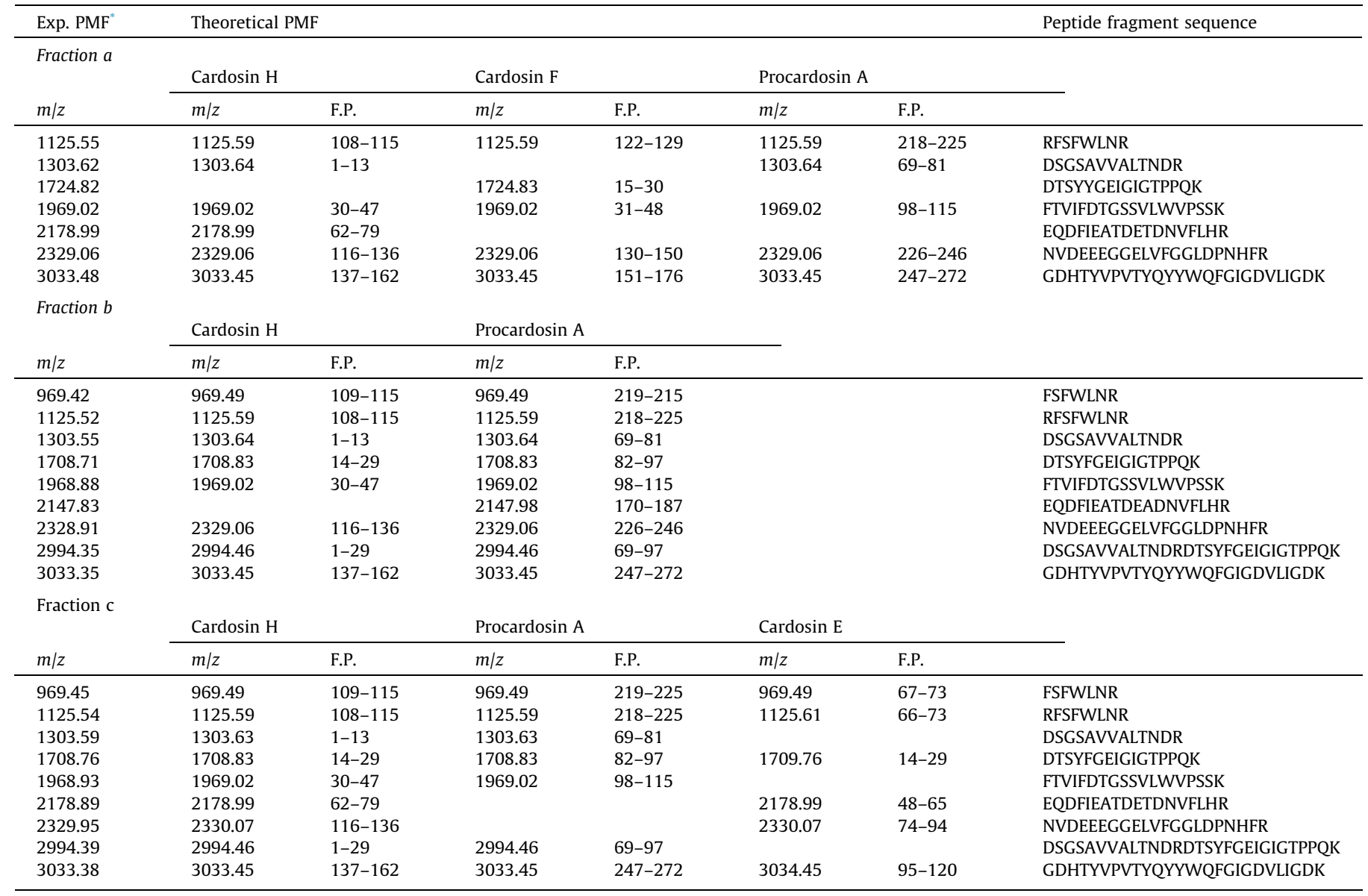

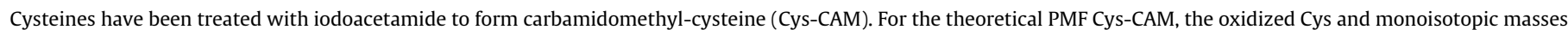
of the occurring amino acid residues obtained were considered. The experimental and theoretical peptide matches were selected with a mass tolerance of 50 ppm.

* PMF, peptide-mass fingerprints.

determined from an N-terminal sequencing of the 13.0 - and 12.5 kDa bands. The APs generally display specificity for amino-acid residues on either side of the scissile bond containing large hydrophobic side chains such as those involved in the aforementioned cleavages. For example, when the cleavage specificity of the card- osin A from $C$. cardunculus and $C$. humilis was evaluated with bovine $\alpha_{\mathrm{s} 1}$-casein and caprine $\alpha_{\mathrm{s} 2}$-casein, the (Tyr165-Tyr166) and (Tyr186-Tyr187) bonds, respectively, were found to be hydrolyzed (Ramalho-Santos, Veríssimo, Faro, \& Pires, 1996; Silva \& Malcata, 2000). Although these APs can cleave those bonds in a simplified 


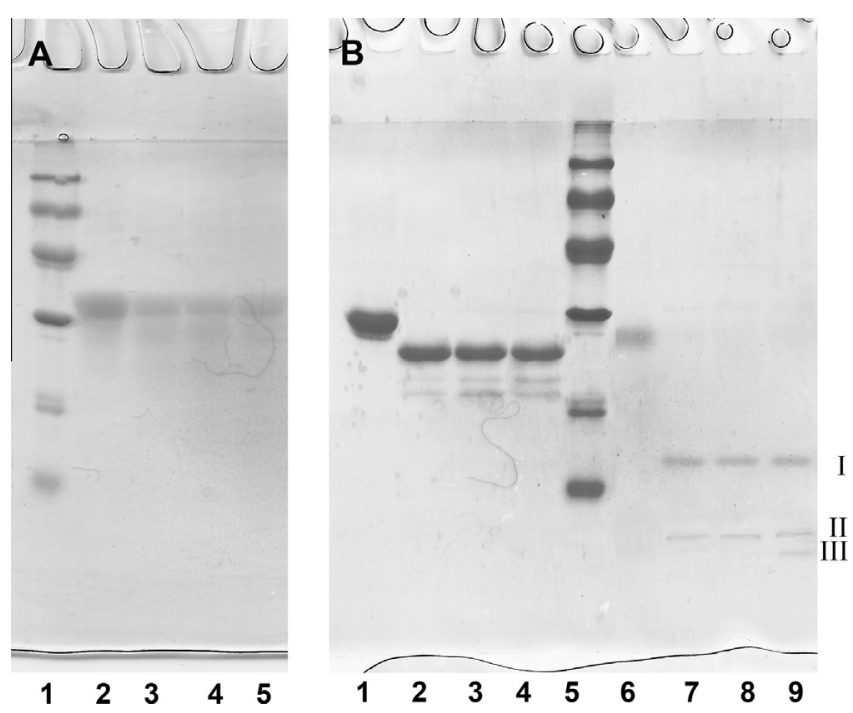

Fig. 2. Hydrolysis of caseins by fractions from C. scolymus flower extract. SDS-PAGE electrophoretogram $(12.5 \%[\mathrm{w} / \mathrm{v}]$, preceded by a stacking gel of $4 \%[\mathrm{w} / \mathrm{v}]$, polyacrylamide). (A) Degradation patterns of $\alpha$-casein by fractions $b-d$. Lane 1 , molecular-weight standards (phosphorylase b, $97.0 \mathrm{kDa}$; albumin, $66.0 \mathrm{kDa}$; ovalbumin, $45.0 \mathrm{kDa}$; carbonic anhydrase, $30.0 \mathrm{kDa}$; trypsin inhibitor, $20.1 \mathrm{kDa}$; $\alpha$-Lactalbumin, $14.4 \mathrm{kDa}$ ); Lane 2, $\alpha$-casein after incubation for $0 \mathrm{~min}$; lanes 3-5, $\alpha$-casein after 30 min of hydrolysis by fractions $b-d$. (B) Degradation patterns of $\kappa$ - and $\beta$-bovine caseins by fractions $b-d$. Lanes 1 and $6, \beta-$ and $\kappa$-caseins, respectively, after incubation for $0 \mathrm{~min}$; lanes $2-4, \beta$-casein after $30 \mathrm{~min}$ of hydrolysis by fractions $b-d$, respectively; Lane 5 , molecular-weight standards (same as Panel A, Lane 1); lanes 7-9, $\kappa$-casein after 30 min of hydrolysis by fractions $b-d$, respectively. The $\kappa$-casein major digestion product is indicated by I, ( $15 \mathrm{kDa}$ ); II and III indicate the 13.0- and 12.5 -kDa products resulting from $\kappa$-casein cleavage at the Tyr42-Tyr43 and Leu50-Ile51 bonds, respectively.

experimental system where the $\kappa$-casein is isolated, the same peptide bonds will not necessarily be split during coagulation since casein micelles are a much more complex system.

\subsection{Cheese production and evaluation}

Since in this study cheese making with vegetable (VR) and animal (AR) was performed simultaneously with the same equipment and reagents, the observed differences were mainly attributable to the action of the coagulant used. Both the floral extract and the commercial rennet coagulated milk in about $30 \mathrm{~min}$ at $35^{\circ} \mathrm{C}$, a time suitable for use on an industrial scale. The curd was firm and elastic in all instances and the whey produced was clear, indicating a high efficiency of the enzymes in coagulating the caseins. The change in $\mathrm{pH}$ of the mass obtained was slight, thus permitting a correct pressing. Cheese yields were equal-9\% at the end of ripening-regardless of the type of coagulant used. At the beginning of ripening the VR cheeses showed no differences from the AR cheeses in either texture or color.

For all treatments, the acidity of the whey was $11^{\circ} \mathrm{D}$ when the curd was cut; while the $\mathrm{pH}$ of the mass was 6.37 and 6.49 with VR or with AR, respectively. After cutting, stirring, and washing, the acidity was $9^{\circ} \mathrm{D}(\mathrm{pH} 6.44)$ and $8.5^{\circ} \mathrm{D}(\mathrm{pH}$ 6.58) when using VR and $\mathrm{AR}$, respectively.

In Fig. 3, panels $\mathrm{A}$ and $\mathrm{B}$ show the respective changes in $\mathrm{pH}$ at the surface and at the center of the cheeses over time during the ripening period, while Panel $C$ presents the moisture profile during that ripening. Additional analyses of repeated measurements over time revealed significant differences (Tukey's test, $p<0.01$ ) between the three treatments with respect to both the surface and the center pHs indicating a higher value with the use of the AR than with either of the VR preparations, with the VR-30 continually producing lower $\mathrm{pH}$ values than those of VR-40. At the end of ripening the $\mathrm{pH}$ at the surface of the cheeses was $5.31 \pm 0.03$ for the AR cheeses, and $5.10 \pm 0.05$ and $5.00 \pm 0.06$ for the VR cheeses brined for 30 (VR-30) and $40 \mathrm{~h}$ (VR-40), respectively; whereas the three respective $\mathrm{pHs}$ in the center of those cheeses was $5.30 \pm 0.04$, $5.10 \pm 0.04$, and $5.00 \pm 0.04$ (Fig. 3, Panels A,B). Similar values of pH were reported by Fernández-Salguero and Sanjuán (1999) and Sousa and Malcata (1997a) in an investigation of the biochemical evolution of cheeses made with extract of cardoon flowers.

Variance analysis and a means comparison (Tukey's test) showed no significant moisture differences $(p<0.01)$ at the end of ripening between the VR-40 cheeses and the AR cheeses (Fig. 3, Panel C). An increase in the brining time of the VR cheeses resulted in a reduction in moisture content, thus approximating the percentages of the AR control and at the same time being within the average moisture content of Gouda-type cheeses specified in the FAO Cheesemaking Manual (FAO, 1986).

During the maturation period, the degradation of the caseins was higher in the VR cheeses than in the AR cheeses. This difference meant that the WSN content (as a percentage of the TN, which is a measure of proteolytic activity) of the VR cheeses was approximately twice that of the AR cheeses (Fig. 4). Thus, the average WSN of the last three samples taken (at 30,35, and 44 days) of the VR cheeses (at $21.8 \%$ of the TN) was $108 \%$ higher than the value for the AR cheeses (at 10.5\% of the TN). Vioque et al. (2000) had observed differences in the WSN contents of Los-Pedroches cheeses after renneting by different plant coagulants of the Cardue tribe: for example, the WSN levels of cheeses renneted with extract of C. cardunculus were higher than the values for those treated with C. humilis preparations, but the WSN contents of the latter cheeses was, in turn, much higher than the values obtained for cheeses coagulated through the use of chymosin (Fernández-Salguero \& Sanjuán, 1999). Equivalent results were reported by Sousa and Malcata (1997b) after comparing the production of ovine cheeses renneted with either flower extracts of $C$. cardunculus or AR prepared on a pilot scale. The proteolysis of the present VR cheeses was also influenced by the duration of exposure to salt ( $c f$. Fig. 4): after the sixth day of maturation cheeses brined for the longer period of $40 \mathrm{~h}$ exhibited lower levels of the WSN/TN ratio than those brined for $30 \mathrm{~h}$.

Electrophoretic analyses of the water-insoluble fractions from cheeses manufactured with either type of rennet were performed in order to assess which casein was the more susceptible to proteolysis in these systems. Before curdling, the intact caseins were quantified by gel scanning and densitometry analysis and the amounts of $\alpha$ - and $\beta$-caseins expressed as a percentage of the total insoluble-protein content during cheese ripening (Fig. 5). The degradation rate of both caseins in the AR and VR-40 cheeses was pronounced up to between 10 and 15 days of ripening, respectively, thereafter remaining almost constant until the end of the ripening. In contrast, the rate of casein hydrolysis of the VR-30 cheeses was almost linear throughout the entire 45 days. At the end of ripening, variance analysis and the comparison of means (Tukey's test) indicated no significant differences $(p<0.01)$ between the percentages of $\alpha$-casein degradation after each treatment. With respect to the hydrolysis of $\beta$-casein, no differences were likewise observed between AR and VR-40 cheeses, but both were significantly different from the VR-30 cheeses (Table 1 in Supplementary Data). These results also confirm that proteolysis is influenced by the conditions of brine treatment.

Although slight differences were noted in $\mathrm{pH}$ values and chemical parameters studied for AR and VR cheeses, most data were comparable throughout the ripening process, especially with respect to those salted for $40 \mathrm{~h}$. These results are in agreement with those reported by Galán et al. (2008), who compared the influence of different amounts of vegetable coagulant from cardoon and calf rennet on the production of ovine cheeses. These researchers 

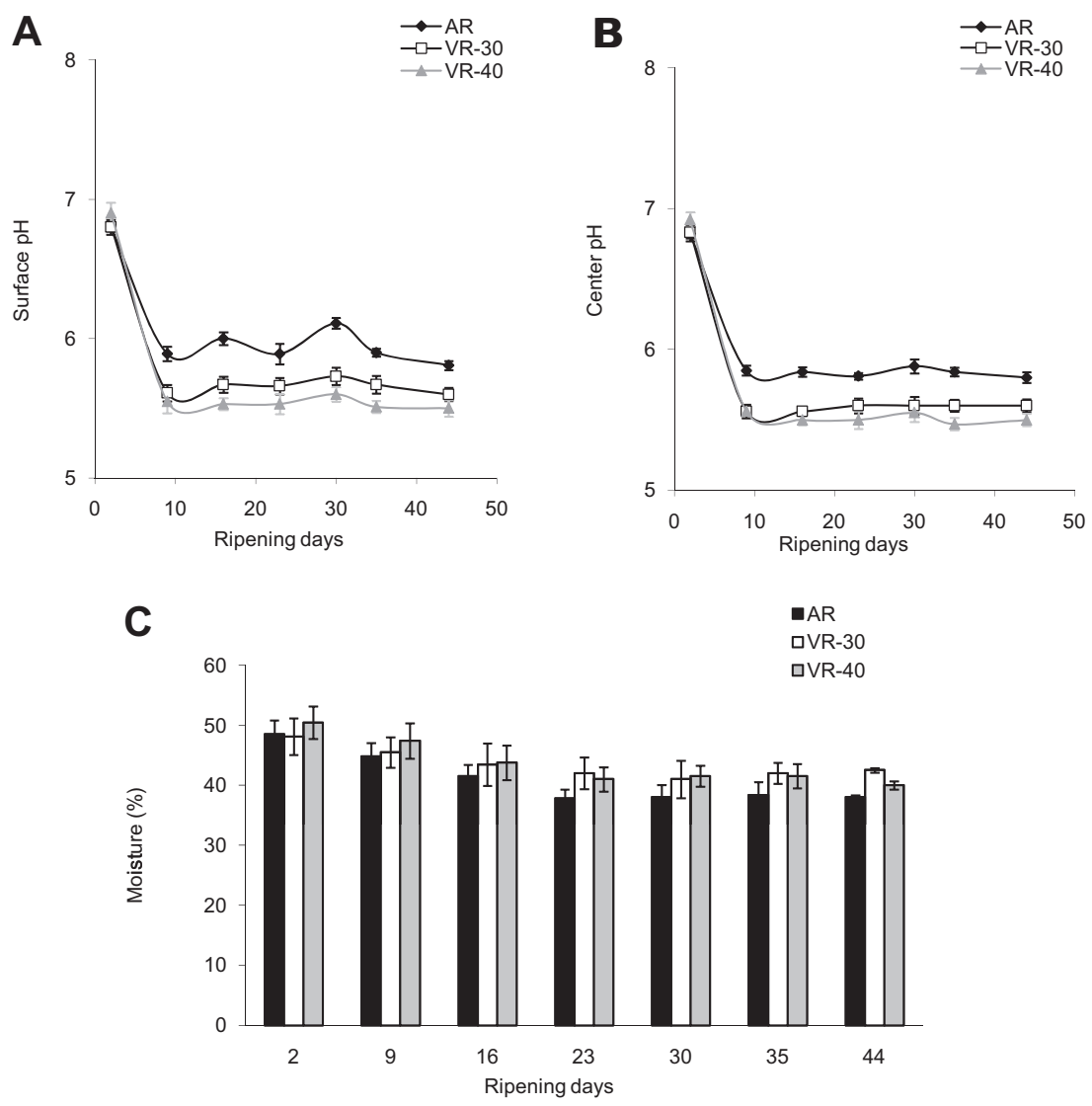

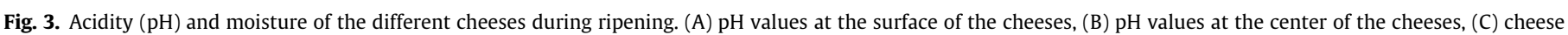
moisture content. Means \pm standard error.

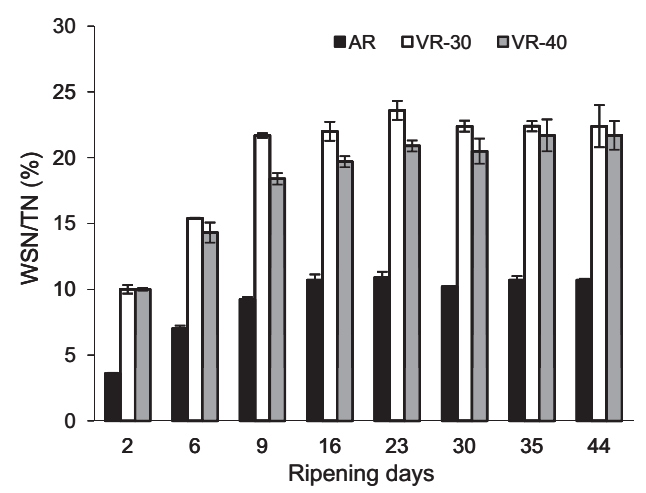

Fig. 4. Water-soluble nitrogen as a percent of the total nitrogen $(\mathrm{WSN} / \mathrm{TN} \times 100)$ during the ripening of AR and VR cheeses salted for 30 or $40 \mathrm{~h}$. Means \pm standard error.

observed no differences between the coagulants assayed for most of the chemical parameters they studied. However, significantly higher levels of casein hydrolysis were observed by them in cheeses produced with the double amount of vegetable rennet compared with those made with normal amount of the same rennet.

A trained sensory panel detected no significant differences between the three manufacturing conditions in the overall external and internal characteristics (in terms of appearance; uniformity; color; and the quantity, the size, and the distribution of the eyes present) and the texture (i.e., elasticity, hardness, shear strength, and cohesiveness in the mouth). The sensory panel detected a bitter flavor in cheeses elaborated with the VR that was perceived noticeably in the VR-30 cheeses but only slightly in the cheeses kept in brine for $40 \mathrm{~h}$. Similar results had been found by Brutti et al. (2012) when a trained sensory panel compared two commercial semihard cheeses with a cheese manufactured by treatment with an extract of $O$. acanthium. Cheese flavor is the end product of complex biochemical reactions, where in fact the proteolysis of cheeses during ripening plays a key role in the development of textural changes within the cheese matrix-i.e. agreeable flavor versus an off-flavor (Sousa, Ardö, \& Mcsweeney, 2001). The concerted action of a protease carried over from milk clotting, the indigenous milk proteases, and the starter proteases provides suitable substrates for the starter peptidases, whose hydrolysis ultimately generates small peptides and free amino acids (Visser, 1993). The quantity of coagulant that is retained in cheese curd varies with the variety of cheese. With the Gouda type, the residual rennet activity could be about $15 \%$ of the original amount added, but also depends on the class and ratio of enzymes in the particular rennet used, those enzymes' stabilities to $\mathrm{pH}$ and temperature during the cheese making, and the influence of $\mathrm{pH}$ on the ability of the enzymes to bind to the caseins (Bansal, Fox, \& Mcsweeney, 2009). Immersing the VR-curdled cheeses in brine for the longer period (i.e., $40 \mathrm{~h}$ ) prevented overproteolysis in these cheeses, thus avoiding the development of a background flavor. A balanced breakdown of the curd proteins into small peptides and free amino acids is necessary for the development of acceptable flavors and is determined by the choice of ripening conditions-i.e., the storage temperature, relative humidity in the ripening room, and the duration of the ripening period (Forde \& Fitzgerald, 2000). The presence of sodium chloride influences the flavor of cheeses not only because of its salty taste but also indirectly by affecting the intrinsic catalytic activity of cell-free enzymes (Macedo \& Malcata, 1997), 
A
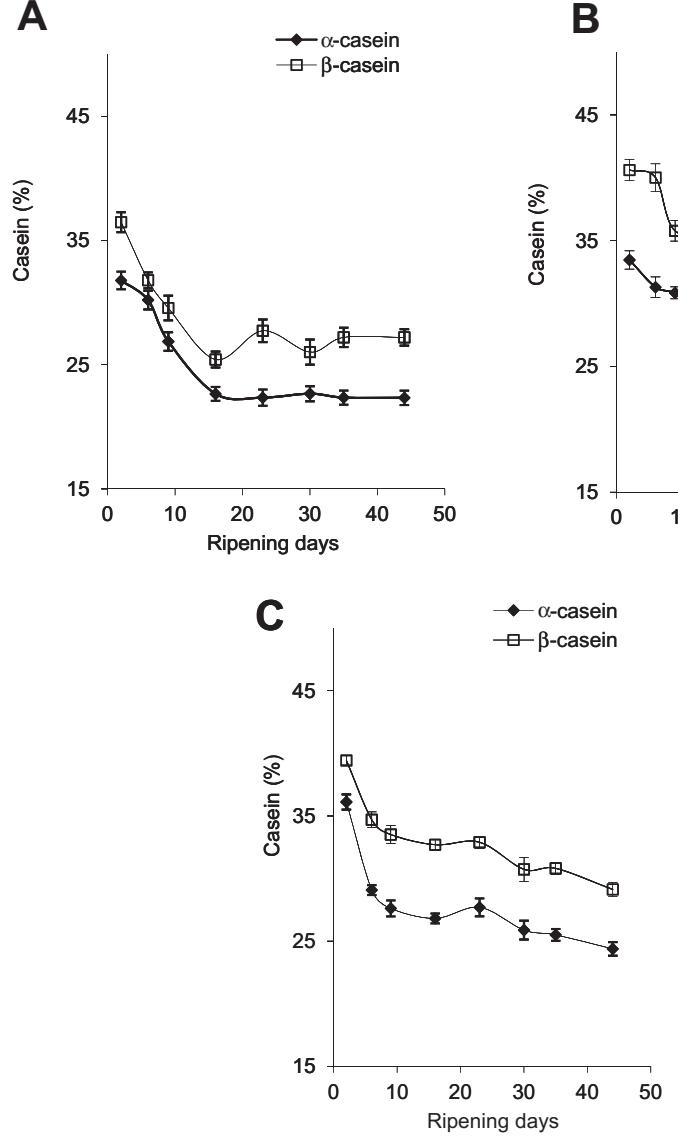

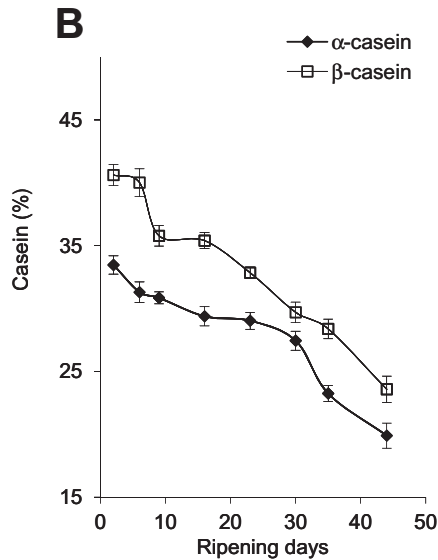

$$
\text { so }
$$


Chazarra, S., Sidrach, L., López-Molina, D., \& Ródriguez-López, J. N. (2007) Characterization of the milk-clotting properties of extracts from artichoke (Cynara scolymus, L.) flowers. International Dairy Journal, 17, 1393-1400.

Cimino, C. V., Liggieri, C. S., Priolo, N. S., Bruno, M. A., \& Vairo-Cavalli, S. E. (2010). Arctium minus (Hill) Bernh. (Asteraceae) aspartylendopeptidases with potential application in the formulation of nutraceutical products. Molecular Medicinal Chemistry, 21(April), 11-16.

Dalgleish, D. G. (1987). The enzymatic coagulation of milk. In P. Fox (Ed.), Cheese: Chemistry, physics and microbiology (pp. 63-111). London: Elsevier.

Domingos, A., Cardoso, P. C., Xue, Z., Clemente, A., Brodelius, P. E., \& Pais, M. S. (2000). Purification, cloning and autoproteolytic processing of an aspartic proteinase from Centaurea calcitrapa. FEBS Journal, 267, 6824-6831.

FAO. (1986). Fundamentos químicos, físicos y microbiológicos en la elaboración y maduración de quesos. In Manual de Elaboración de Quesos. Equipo Regional de Fomento y Capacitación en Lechería. Santiago de Chile: Equipo Regional de Fomento y Capacitación en Lechería. FAO para América Latina.

Fernández-Salguero, J., \& Sanjuán, E. (1999). Influence of vegetable and animal rennet on proteolysis during ripening in ewes' milk cheese. Food Chemistry, 64, $177-183$.

Forde, A., \& Fitzgerald, G. F. (2000). Biotechnological approaches to the understanding and improvement of mature cheese flavour. Current Opinion in Biotechnology, 11(5), 484-489.

Galán, E., Prados, F., Pino, A., Tejada, L., \& Fernández-Salguero, J. (2008). Influence of different amounts of vegetable coagulant from cardoon Cynara cardunculus and calf rennet on the proteolysis and sensory characteristics of cheeses made with sheep milk. International Dairy Journal, 18, 93-98.

Jacob, M., Jaros, D., \& Rohm, H. (2011). Recent advances in milk clotting enzymes. International Journal of Dairy Technology, 64(1), 14-33.

Laemmli, U. K. (1970). Cleavage of structural proteins during the assembly of the head of bacteriophage T4. Nature, 227, 680-685.

Lane, C. N., Fox, P. F., Johnston, D. E., \& McSweeney, P. L. H. (1997). Contribution of coagulant to proteolysis and textural changes in cheddar cheese during ripening. International Dairy Journal, 7(97), 453-464.

Lawless, H. T., \& Heymann, H. (1999). Sensory evaluation of food. Principles and practices (1st ed.). New York: Springer.

Llorente, B. E., Brutti, C. B., \& Caffini, N. O. (2004). Purification and characterization of a milk-clotting aspartic proteinase from globe artichoke (Cynara scolymus L.). Journal of Agricultural and Food Chemistry, 52(26), 8182-8189.

Llorente, B. E., Brutti, C. B., Natalucci, C. L., \& Caffini, N. O. (1997). Partial characterization of a milk clotting proteinase isolated from artichoke (Cynara scolymus L., Asteraceae). Acta Farmacéutica Bonaerense, 16, 37-42.

Lourenço, P. M., de Castro, S., Martins, T. M., Clemente, A., \& Domingos, A. (2002) Growth and proteolytic activity of hairy roots from Centaurea calcitrapa: effect of nitrogen and sucrose. Enzyme and Microbial Technology, 31(suppl. 3), $242-249$.

Lufrano, D., Faro, R., Castanheira, P., Parisi, G., Veríssimo, P., Vairo-Cavalli, S., et al. (2012). Molecular cloning and characterization of procirsin, an active aspartic protease precursor from Cirsium vulgare (Asteraceae). Phytochemistry, 81, 7-18.

Macedo, A. C., \& Malcata, F. X. (1997). Technological optimization of the manufacture of serra cheese. Journal of Food Engineering, 31, 433-447.

Pimentel, C., Van Der Straeten, D., Pires, E., Faro, C., \& Rodrigues-Pousada, C. (2007) Characterization and expression analysis of the aspartic protease gene family of Cynara cardunculus L. FEBS Journal, 274(10), 2523-2539.

Ramalho-Santos, M., Veríssimo, P., Faro, C. J., \& Pires, E. (1996). Action on bovine alpha s1-casein of cardosins A and B, aspartic proteinases from the flowers of the cardoon Cynara cardunculus L. Biochimica et Biophysica Acta, 1297(1), 83-89.
Reis, P. J. M., \& Malcata, F. X. (2011). Current state of Portuguese dairy products from ovine and caprine milks. Small Ruminant Research, 101(1-3), 122-133.

Roseiro, L. B., Barbosa, M., Ames, J. M., \& Wilbey, R. A. (2003). Cheesemaking with vegetable coagulants-the use of Cynara $\mathrm{L}$. for the production of ovine milk cheeses. Int J Dairy Technol, 56(2), 76-85.

Rusconi, M. E., Priolo, N. S., López, L. M. I., \& Vairo Cavalli, S. E. (2011). Action of Silybum marianum (L.) Gaertn peptidases on bovine caseins. Alimentaria, 421, 90-95.

Sampaio, P. N., Fortes, A. M., Cabral, J. M. S., Pais, M. S., \& Fonseca, L. P. (2008). Production and characterization of recombinant Cyprosin B in Saccharomyces cerevisiae (W303-1A) Strain. Journal of Bioscience and Bioengineering, 105(4), 305-312.

Sarmento, A. C., Lopes, H., Oliveira, C. S., Vitorino, R., Samyn, B., Sergeant, K., et al. (2009). Multiplicity of aspartic proteinases from Cynara cardunculus L. Planta, 230(2), 429-439.

Shalabi, S., \& Fox, P. (1982). Influence of $\mathrm{pH}$ on the rennet coagulation of milk. J Dairy Res, 49, 153-157.

Shalabi, S., \& Fox, P. (1987). Electrophoretic analysis of cheese: comparison of methods. Irish Journal of Food Sciences and Technology, 11, 135-151.

Sidrach, L., García-Cánovas, F., Tudela, J., \& Rodríguez-López, J. N. (2005). Purification of cynarases from artichoke (Cynara scolymus L.): Enzymatic properties of cynarase A. Phytochemistry, 66(1), 41-49.

Silva, S. V., \& Malcata, F. X. (2005). Studies pertaining to coagulant and proteolytic activities of plant proteases from Cynara cardunculus. Food Chemistry, 89, 19-26.

Silva, S. V., \& Malcata, F. X. (2000). Action of cardosin A from Cynara humilis on ovine and caprine caseinates. Journal of Dairy Research, 67, 449-454.

Sousa, M., Ardö, Y., \& Mcsweeney, P. (2001). Advances in the study of proteolysis during cheese ripening. International Dairy Journal, 11(4-7), 327-345.

Sousa, M., \& Malcata, F. (1997a). Comparison of plant and animal rennets in terms of microbiological, chemical, and proteolysis characteristics of ovine cheese. Journal of Agricultural and Food Chemistry, 45(1), 74-81.

Sousa, M., \& Malcata, F. (1997b). Ripening of ovine milk cheeses: Effects of plant rennet, pasteurization, and addition of starter on lipolysis. Food Chemistry, 59(3), 427-432.

Tamer, I. M. (1993). Identification and partial purification of a novel milk clotting enzyme from Onopordum turcicum. Biotechnology Letters, 15(4), 427-432.

Tejada, L., Vioque, M., Gómez, R., \& Fernández-Salguero, J. (2008). Effect of lyophilisation, refrigerated storage and frozen storage on the coagulant activity and microbiological quality of Cynara cardunculus L. extracts. Journal of the Science of Food and Agriculture, 88(8), 1301-1306.

Vairo Cavalli, S., Lufrano, D., Colombo, M. L., \& Priolo, N. (2013). Properties and applications of phytepsins from thistle flowers. Phytochemistry, 92, 16-32.

Vairo Cavalli, S., Silva, S., Cimino, C., Malcata, F. X., Priolo, N., \& Vairocavalli, S. (2008). Hydrolysis of caprine and ovine milk proteins, brought about by aspartic peptidases from Silybum marianum flowers. Food Chemistry, 106(3), 997-1003.

Veríssimo, P., Esteves, C. L., Faro, C. J., \& Pires, E. (1995). The vegetable rennet of Cynara cardunculus L. contains two proteinases with chymosin and pepsin-like specificities. Biotechnology Letters, 17(6), 621-626.

Vioque, M., Gómez, R., Sánchez, E., Mata, C., Tejada, L., \& Fernández-Salguero, J. (2000). Chemical and microbiological characteristics of ewes' milk cheese manufactured with extracts from flowers of Cynara cardunculus and Cynara humilis as coagulants. Journal of Agricultural and Food Chemistry, 48(2), 451-456.

Visser, S. (1993). Proteolytic enzymes and their relation to cheese ripening and flavor: An overview. Journal of Dairy Science, 76, 329-350. 